ks. Janusz Królikowski

ORCID: 0000-0003-3929-6008

Uniwersytet Papieski Jana Pawła II w Krakowie

\title{
Kościół na wzór Jezusa Chrystusa w perspektywie II Soboru Watykańskiego
}

II Sobór Watykański, dokonując szerokiej i pogłębionej teologicznie prezentacji Kościoła, jego natury i misji, zwrócił trafnie uwagę na jego rys chrystologiczny. Eklezjologia soborowa może być uznana za integralny i konieczny rozdział chrystologii ${ }^{1}$ Są oczywiście podstawy, by mówić o niej także jako eklezjologii trynitarnej ${ }^{2}$, a nawet pneumatologicznej, niemniej jednak pozostaje ona dominująco chrystocentryczna ${ }^{3}$. Takie rozumienie wyrasta z doświadczeń Kościoła, których nabył on w ciągu prawie dwóch tysiącleci swego istnienia, ale i tych, które miały miejsce w ciągu dwóch ostatnich wieków, począwszy od epoki romantyzmu. To w tej epoce zwrócono większą uwagę na wiarę w Jezusa Chrystusa urzeczywistniającą się przede wszystkim w żywym i mistycznym organizmie Kościoła, co przyczyniło się do wyraźnego uduchowienia wizji Kościoła w stosunku do wizji wyrastającej z reform gregoriańskich i odnowy trydenckiej. Powrócono do teologii Kościoła jako mistycznego Ciała Chrystusa. Choć takie pojmowanie Kościoła było przełomowe i jako takie jest nie

1 Por. K. Wojtyła, Kościót w tajemnicy odkupienia. Interpretacja Vaticanum II, wybór i oprac. A. Dobrzyński, Rzym 2012, s. 334-336.

2 Por. M. Philipon, La Santissima Trinità e la Chiesa, w: La Chiesa del Vaticano II. Studi e commenti intorno alla costituzione dommatica "Lumen gentium”, opera collettiva diretta da G. Baraúna, Firenze 1965, s. 329-350.

3 Por. B. Forte, La Chiesa, icona della Trinità. Breve ecclesiologia, Brescia 1985; D. Valentini, Lo Spirito, la Chiesa e l'uomo. Studi di ecclesiologia e di ecumenismo, Roma 2017, s. 31-42. 
do przecenienia, czego dowodzi niezwykle ważna encyklika eklezjologiczna Mystici Corporis Piusa XII (29 czerwca 1943 r.), szybko okazało się niewystarczające ${ }^{4}$. Niemal równocześnie z ogłoszeniem tej encykliki zaczęła zyskiwać na znaczeniu (oczywiście już wcześniej dostrzeżona) wizja Kościoła, która $\mathrm{w}$ jego rozumieniu nadaje pierwszeństwo pojęciu sakramentu. Jest to wizja, która wyraźnie doszła do głosu w czasie obrad soborowych, a jej manifestem stała się konstytucja dogmatyczna Lumen gentium. Już w jej pierwszym punkcie zostało powiedziane: „Kościół jest w Chrystusie jakby sakramentem, czyli znakiem i narzędziem wewnętrznego zjednoczenia z Bogiem i jedności całego rodzaju ludzkiego". W tej perspektywie należy odczytywać całą eklezjologię soborową, która jest przede wszystkim eklezjologią sakramentalną, a w związku z tym także właściwie chrystologiczną. Oczywiście musimy być świadomi, że teologia Kościoła jako sakramentu zbawienia ciągle czeka na właściwe uwzględnienie w eklezjologii.

Wymowa i siła rozumienia Kościoła jako sakramentu wynika z tego, że najbardziej ściśle i bezpośrednio wyraża ono jednoczącą więź zachodzącą między Jezusem Chrystusem i Kościołem - więź stojącą u początków Kościoła, ale także wielorako konkretyzującą się i historycznie przedłużającą w ciągu wieków. Jak Jezus Chrystus jest prawdziwym Bogiem i prawdziwym człowiekiem w jednej osobie wiecznego Słowa, a więc Prasakramentem, tak Kościół w swojej wewnętrznej naturze posiada wymiar boski i wymiar ludzki, które potem wewnętrznie zjednoczone ze sobą manifestują się w ciągu wieków w Kościele historycznym w kontynuowaniu przez niego misji zbawczej Jezusa Chrystu$\mathrm{sa}^{6}$. Jak ludzka natura Słowa Wcielonego stała się narzędziem zbawienia i jedności rodzaju ludzkiego, tak widzialny wymiar Kościoła i wieloraka działalność Kościoła służą coraz pełniejszemu urzeczywistnianiu się i utrwalaniu dzieła zbawczego, zakorzenionego w niewidzialnej tajemnicy Jezusa Chrystusa. Połączone ze sobą dwa wymiary Kościoła, a więc boski i ludzki, mają swój najbardziej bezpośredni wzór w osobowej jedności wiecznego Słowa, które przyjęło ludzkie ciało dla naszego zbawienia. $Z$ tej też racji konstytucja Lumen

4 Por. B. Gherardini, L’enciclica „Mystici Corporis” (29 giugno 1943), w: L'eredità del magistero di Pio XII, ed. Ph. Chenaux, Città del Vaticano 2010, s. 203-217.

5 Por. J. Ratzinger, Kościót jako sakrament zbawienia, w: J. Ratzinger, Kościót - znak wśród narodów. Pisma eklezjologiczne i ekumeniczne, tłum. W. Szymona, Lublin 2013, s. 222-234 (Opera omnia, viII/1).

6 Por. J. Królikowski, Jezus Chrystus prasakrament Boga i zbawienia, „Tarnowskie Studia Teologiczne" 26 (2007) nr 2, s. 3-18. 
gentium nie waha się podkreślić, że mimo rozmaitych ograniczeń „na zasadzie bliskiej analogii [złożona rzeczywistość Kościoła] upodabnia się do misterium Słowa Wcielonego"'.

Wychodząc od tych ogólnych stwierdzeń, można powiedzieć, że Kościół już w swej genezie i na poziomie swojej natury, a więc jako sakrament zbawienia, jest „na wzór Chrystusa”. Każda wypowiedź na ten temat musi odnosić się do tego podstawowego faktu teologicznego, czerpiąc także inspirację do wyprowadzenia $\mathrm{z}$ niego konsekwencji na poziomie urzeczywistniania się misji Kościoła. Kościół, będąc w swojej naturze na wzór Chrystusa, ma zatem także stawać się na Jego wzór w pełnionej misji i podejmowanych dziełach. W niniejszym opracowaniu chodzi o wydobycie zasadniczych perspektyw tego drugiego zagadnienia, a więc opisanie wzorczości Chrystusa w odniesieniu do historycznego urzeczywistniania się Kościoła, a tym samym również jego rozwoju i wewnętrznego postępu urzeczywistnianego w dziejach. Ten opis z oczywistych racji powinien pozostawać w bezpośrednim związku z wzorczością Chrystusa zapisaną w naturze Kościoła. W tym celu zwracamy najpierw uwagę na najbardziej pierwotny aspekt ukonstytuowania Kościoła w Jezusie Chrystusie, czyli jego zapoczątkowanie. Kościół dzisiejszy pozostaje i ma pozostać taki sam, jaki był na początku. Tego domaga się jego natura i to jest gwarancja skuteczności jego misji.

\section{Kościół ukonstytuowany w Chrystusie}

Stwierdzenie, że Kościół - powszechny sakrament zbawienia - w swej genezie jest na wzór Jezusa Chrystusa, domaga się pogłębienia, aby wskazać punkt odniesienia tej wzorczości oraz wydobyć jej kluczowe aspekty. Tym punktem odniesienia jest chrystologiczny początek Kościoła w Jezusie Chrystusie oraz jego właściwy cel zbawczy, a więc odniesienie do Jego dzieła zbawczego. Uszczegółowienie tego odniesienia wiąże się ze specyfiką posługi urzędowej w Kościele, która stanowi historyczne przedłużenie chrystologicznej genezy Kościoła.

\footnotetext{
7 Sobór Watykański II, Konstytucja dogmatyczna o Kościele Lumen gentium [dalej: LG], nr 8, w: Sobór Watykański II, Konstytucje, dekrety, deklaracje, Poznań 2002.

8 Por. Jan Paweł II, Katecheza w czasie audiencji generalnej (6 sierpnia 1997 r.), nr 4, „L'Osservatore Romano" (wyd. pol.) 18 (1997) nr 11, s. 21; Franciszek, Adhortacja apostolska Evangelii gaudium (24 listopada 2013), Kraków 2013, nr 23.
} 
Historyczny początek Kościoła i jego cel

U początków Kościoła znajduje się zamysł Ojca, określony przed stworzeniem świata. Konstytucja Lumen gentium zaczyna się od nawiązania do tego zamysłu Bożego, pokazując następnie, w jaki sposób został on urzeczywistniony przez posłanie Syna. Tym, co jest najbardziej właściwe dla działania Syna, jest Jego obecność i Jego „acta et passa” urzeczywistnione w dziejach ludzkich, mające na celu ukonstytuowanie Kościoła i wyposażenie go w dary odpowiednie do zleconej mu misji. Sobór wyraźnie określa i podkreśla trynitarną genezę Kościoła, „ludu zjednoczonego jednością Ojca i Syna, i Ducha Świętego” (LG 4)9. Ta geneza trynitarna, która oznacza wspólne działanie osób Bożych w ukonstytuowaniu Kościoła, nie pozbawia jednak żadnej z tych osób właściwego dla niej sposobu działania oraz odpowiedniego sposobu przyjmowania tego działania ze strony Kościoła. Wcielił się tylko Syn Boży, a w ten sposób „zapoczątkował królestwo Boże na ziemi” (LG 3).

To zapoczątkowanie królestwa Bożego urzeczywistniało się na różne sposoby i w zróżnicowany sposób wpływało na ukonstytuowanie Kościoła. Wyraziło się ono za pośrednictwem działania ludzkiego Słowa Wcielonego, różniącego się jednak od działania innych założycieli instytucji ludzkich, ponieważ chodzi w nich o działanie Syna, Boga i Pana. Na pierwszym miejscu sytuuje się Jego przepowiadanie: „Pan Jezus zapoczątkował swój Kościół, głosząc radosną nowinę, a mianowicie nadejście królestwa Bożego obiecanego od wieków w Piśmie Świętym" (LG 5). To przyjście zostaje mocno potwierdzone za pośrednictwem cudów. Przede wszystkim należy jednak rozpoznać objawienie królestwa „w osobie Chrystusa, Syna Bożego i Syna Człowieczego". W konstytucji Lumen gentium szczególnie została uwypuklona męka Chrystusa, ponieważ przyszedł On, ,żeby służyć i dać swoje życie jako okup za wielu” (Mk 10, 45). Nawiązując do tych słów, sobór podkreśla, że działalność założycielska Jezusa nie tylko polegała na zebraniu wokół siebie tych, którzy Go słuchali i widzieli Jego czyny, ale wyraziła się w wyzwoleniu ludzkości z grzechu za pośrednictwem Jego ofiary i obdarowaniu jej nowym prawem wolności i łaski. Początek i wzrost Kościoła jest oznaczany przez „krew i wodę wypływające z otwartego boku ukrzyżowanego Jezusa” (LG 3), co zapowiedziały Jego słowa: „A Ja, gdy zostanę nad ziemię wywyższony, przyciągnę wszystkich do siebie" (J 12, 32).

Po śmierci na krzyżu następuje zmartwychwstanie, które ukazuje Chrystusa jako „Pana, Mesjasza i Kapłana ustanowionego na wieki”, który „wylał na swoich uczniów Ducha obiecanego przez Ojca” (LG 5). Wraz z ustanowieniem

\footnotetext{
9 Cytuje s. Cypriana.
} 
Kościoła zaczyna się więc działanie Chrystusa w dziejach ludzkich, a wypełnia się ono za pośrednictwem działania przekraczającego dzieje, ponieważ Zmartwychwstały, jako wywyższony i chwalebny Pan, posyła swego Ducha. W Nim Chrystus nieustannie kontynuuje w ciągu wieków swoją misję zbawczą, oświeca człowieka i prowadzi go do pełni prawdy.

Należałoby tutaj pełniej powiedzieć, że zgodnie z doktryną soborową początek Kościoła poprzedza dzieje, ponieważ znajduje się on w pierwotnym zamyśle Ojca; został on ukryty w wieczności Boga. Syn Boży, za pośrednictwem swego wcielenia, dokonuje przejścia $\mathrm{z}$ wieczności w czas, a w ten sposób zapoczątkowuje Kościół w czasie bądź też „czas Kościoła”. Powracając do wieczności, pozostaje On jednak pierwszą i nienaruszalną zasadą życia i rozwoju Kościoła w czasie. Zmartwychwstanie pozwala Chrystusowi wylać swego Ducha, który będzie kontynuował w czasie Kościoła Jego zbawcze dzieło i prowadził je do spełnienia eschatologicznego.

Wszystkie zapisane tutaj stwierdzenia mają ogólny charakter, przy czym ewidentnie nawiązują do licznych wypowiedzi biblijnych, uwypuklając zarazem ich wyraźną zbieżność treściową. Dzięki tej wierności danym biblijnym sobór mógł zaproponować całościową i autentyczną wizję ukonstytuowania Kościoła, jednoznacznie ilustrującą, że jest on Kościołem w Jezusie Chrystusie, noszącym wyraźne rysy Jego osoby i Jego działań. Można więc powiedzieć, że w swoim wykładzie sobór dobrze zilustrował początkowe stwierdzenie, że na obliczu Kościoła jaśnieje blask Chrystusa (LG 1). Ten blask jest niewątpliwie darem samego Chrystusa, ale pozostaje także zadaniem do podjęcia i do dalszego urzeczywistniania, aby w dalszym ciągu mogły się ukazywać w świecie Jego światło i Jego blask. Nosząc na sobie oblicze Chrystusa, Kościół jest więc wezwany do jego unaocznienia historycznego w konkretnych sytuacjach duchowych zmieniających się czasów. Kościół spełnia to zadanie przede wszystkim wtedy, gdy realnie rozwija się historycznie i poszerza zasięg swego oddziaływania aż na krańce świata.

\section{Ustanowienie posługi urzędowej}

Dokonując ukonstytuowania Kościoła, Chrystus dokonał przede wszystkim ustanowienia posług mających charakter urzędowy. Nawet jeśli z wielu powodów był to proces bardzo złożony, można z całą pewnością wskazać momenty, w których ten proces konkretyzuje się i wyraża w posługach, które można nazwać sakramentalno-urzędowymi. Gdy II Sobór Watykański mówi o hierarchicznej strukturze Kościoła, zaczyna od jednoznacznego stwierdzenia, że dla prowadzenia i rozwoju nowego ludu Bożego „Chrystus Pan ustanowił 
w swoim Kościele rozmaite posługi” (LG 18). Nawiązując do nauczania I Soboru Watykańskiego, według którego „Jezus Chrystus, Pasterz wiekuisty, założył Kościół święty, posławszy Apostołów, tak jak sam został posłany przez Ojca (por. J 20, 21)”, konstytucja Lumen gentium chce zdecydowanie podkreślić, że posłanie apostołów jest aktem wpisującym się jednoznacznie w ukonstytuowanie Kościoła i zleconą mu misję zbawczą. Wyraża ono jasno wolę Chrystusa odnośnie do sukcesji: „Chciał też, aby ich [= apostołów] następcy, mianowicie biskupi, byli w Jego Kościele pasterzami aż do skończenia świata” (LG 18). Sobór uzasadnia to stwierdzenie, wskazując przede wszystkim na trwały charakter tego posłania: „Boskie posłannictwo powierzone przez Chrystusa Apostołom trwać będzie do końca wieków” (LG 20), ponieważ Ewangelia ma być te Wypowiedzi te oznaczają, że struktura hierarchiczna Kościoła ma swoją genezę w samym Jezusie Chrystusie - to On chciał, aby Kościół miał strukturę „episkopalną" i aby ona stanowiła podstawę jego urzeczywistniania się w pełnionej misji zbawczej.

Z tą strukturą episkopalną ściśle łączy się i do niej należy prymat Piotra i jego następców. Konstytucja Lumen gentium także w tej kwestii odwołuje się do nauczania I Soboru Watykańskiego: „Żeby zaś episkopat był jeden i niepodzielny, [Chrystus] postawił nad innymi Apostołami św. Piotra i w nim ustanowił trwałą i widzialną zasadę i fundament jedności wiary i komunii” (LG 18). Sobór nie ograniczył się jedynie do wyraźnego wskazania genezy struktury episkopalnej Kościoła, lecz dokonał również jej uzasadnienia chrystologicznego, odwołując się do świadectw biblijnych. Ustanowienie Dwunastu stanowi więc w Nowym Testamencie jedno z najbardziej charakterystycznych wydarzeń w życiu publicznym Jezusa, które domaga się niemal pierwotnej afirmacji eklezjalnej, a tym samym teologicznej. Kardynał Joseph Ratzinger wskazał na ten fakt syntetycznym stwierdzeniem: „Lud Boży istnieje jako wspólnota tych, którzy stali się towarzyszami losu Jezusa" ${ }^{\text {"10 }}$. Nawet jeśli nie było to całkiem słuszne, jest na pewno zrozumiałe, dlaczego tradycyjna teologia przede wszystkim w tym właśnie fakcie widziała ustanowienie Kościoła przez Chrystusa. Znaczenie ustanowienia Dwunastu wyraża się w Jego modlitwie, która je poprzedziła i w niezależnej woli, którą dokonał On wyboru: „Apostołów [...] których ustanowił jako kolegium, czyli jako stały zespól, na którego czele postawił wybranego spośród nich Piotra” (LG 19). Kolegialność biskupów, o której szeroko naucza II Sobór Watykański, wynikająca z tego pierwotnego gestu

${ }^{10}$ J. Ratzinger, Los Jezusa a Kościół, w: J. Ratzinger, Kościół - znak wśród narodów..., dz. cyt., S. 120. 
Chrystusa, jest więc Jego suwerennym dziełem i zasadą działania Kościoła. Ma ona wyraźne potwierdzenie w całym Nowym Testamencie. Jezus powierza apostołom i ich następcom misję „gromadzenia Kościoła powszechnego”, „krzewienia Kościoła”, głoszenia Ewangelii, posługiwania, uświęcania i bronienia Kościoła. Mają oni pamiętać zawsze i wszędzie, że „kamieniem węgielnym tej budowli jest sam Jezus Chrystus" (LG 19). Przywołane stwierdzenia opisują istotne funkcje biskupie, ale - co należy podkreślić - nie są to ich funkcje „własne”, bowiem mają one bezpośrednie odniesienie do Chrystusa i w odniesieniu do Niego następuje ich aktualizacja w Kościele. Są oni w najwyższym stopniu Chrystusowi w służbie Jego najwyższego dzieła zbawczego, którego On pozostaje sprawcą i które aktualizuje w Duchu Świętym.

Chrystus jawi się jako Założyciel struktury hierarchicznej, która obejmuje kolegium biskupie i prymat papieski. Sobór jest bardziej powściągliwy, jeśli chodzi o początek posługi prezbiterów; ogranicza się do stwierdzenia, że biskupi „w sposób prawomocny przekazali misję swego posługiwania w różnym stopniu różnym osobom w Kościele" (LG 28). Czy jednak chodzi w tym przypadku tylko o zwykłą inicjatywę biskupów? Czy jest ona wyrazem woli Chrystusa? Sobór nie poszedł dalej w swoich wypowiedziach, ponieważ teologia posługi nie dała dotychczas na te pytania jednoznacznej odpowiedzi. Ewangeliczne wydarzenie posłania siedemdziesięciu dwóch uczniów, posłania, które - według świadectwa św. Łukasza (10, 1-20) - jest podobne do posłania powierzonego Dwunastu, powinno zwrócić większą uwagę na wolę Jezusa wyrażoną w tym akcie. Zmierzał On - jak się wydaje, gdy patrzymy na pierwotny Kościół - do tego, aby dostarczyć odpowiednich współpracowników tym, którzy otrzymują do wypełnienia najwyższe zadanie posługi pasterskiej. Uwzględnienie takiej woli Chrystusa pozwoliłoby w większym stopniu widzieć Go jako założyciela całej struktury posługi kapłańskiej w Kościele.

Zwracając w punkcie wyjścia uwagę na znaczenie hierarchii w Kościele, nie zamierzamy tutaj budować jakiejś hierarchio-centrycznej wizji Kościoła, ponieważ była ona już zaproponowana w historii i ewidentnie nie zdała egzaminu. Chodzi przede wszystkim o podkreślenie, że hierarchia jest pierwszym wyrazem jedności Kościoła z Chrystusem, a więc pierwotnie na hierarchii kościelnej spoczywa zadanie zakorzenienia w Jezusie Chrystusie oraz osobowego wyrażania tego faktu, że Kościół należy do Chrystusa i ma być budowany na Jego wzór. Taki jest pierwotny sens pojęcia hierarchia - oznacza ono zgodnie z grecką etymologią (hiera-arche) „święty początek”, „święte źródło”. Być „hierarchą" za pośrednictwem przyjętych święceń oznacza złączyć się wewnętrznie z Jezusem Chrystusem, przeżywać to zjednoczenie i przede wszystkim za Jego 
pośrednictwem oddziaływać $w$ ramach pełnionej misji eklezjalnej. Nie ulega więc wątpliwości, że hierarchia stanowi podstawowy wyraz jedności Kościoła z Jezusem Chrystusem. Ten fakt domaga się zatem odpowiedniego odczytania i wyraźnego włączenia w nasze spojrzenie na Kościół szukający swojego skonkretyzowania chrystologicznego. W tym świetle będzie można potem dokonać chrystologicznego odczytania innych aspektów i wymiarów życia kościelnego.

\section{Chrystus zasadą życia Kościoła i jego wzorem}

Jezus Chrystus nie tylko jest historycznym założycielem Kościoła, ale zachowuje z nim na zawsze trwałą więź; pozostając w chwale, jest On pierwszą zasadą jego rozwoju i jego życia, a także ostatecznym punktem dojścia, a tym samym i jego spełnienia. Odwołując się do tej zasady, należy także poszukiwać w Nim wzoru dla pełnienia przez Kościół historycznej misji zbawczej i autentycznego realizowania jej poszczególnych aspektów. Zagadnienie to domaga się usytuowania go w szerszej perspektywie, która ściśle łączy się ze zrozumieniem natury, a tym samym także specyfiki Kościoła.

\section{Różnorodność obrazów}

Mając na uwadze wyrażenie podstawowej więzi łączącej Chrystusa i Kościół oraz wydobycie jej specyfiki, II Sobór Watykański w konstytucji Lumen gentium odwołuje się najpierw do przypomnienia obrazów biblijnych, które odnoszą się do Kościoła i pomagają ukazać jego istotę (LG 6). Nie chodzi w tym przypadku tylko o ogólnikowe odniesienie do źródeł biblijnych, by pokazać Kościół w Biblii, ale o wydobycie ich sensu, posiadającego podstawową nośność teologiczną i religijną oraz oświecającego konkretne życie i doświadczenia chrześcijanina.

Kościół jest więc owczarnią Chrystusa Pasterza; Chrystus ogłasza także, że Bóg jest pasterzem swojego ludu. Kościół jest rolą Bożą, na której został zasadzony krzew winny - krzew, którym jest sam Chrystus, ożywiający latorośle. Kościół jest budowlą Bożą, której kamieniem węgielnym jest sam Chrystus. Jest on także nazywany domem Bożym i świętą świątynią; do tego obrazu odnosi się wypowiedź Jezusa, gdy mówi o odbudowaniu świątyni Bożej w ciągu trzech dni (por. J 2, 19). Kościół jest opisywany jako oblubienica Baranka. Chrystus jest Oblubieńcem, który pozostaje nierozerwalnie złączony z Kościołem-Oblubienicą od jego początku aż do wypełnienia eschatologicznego.

Ta różnorodność obrazów służy pokazaniu, że Kościół istnieje tylko w odniesieniu do Jezusa Chrystusa; jest prowadzony przez Pasterza, ożywiany przez 
Krzew, zbudowany na Kamieniu Węgielnym, zjednoczony z Oblubieńcem. Rola odgrywana przez Chrystusa w stosunku do Kościoła ma tak wiele znaczeń, że można ją adekwatnie ukazać, tylko odwołując się do wielości form wyrazu i do ich możliwych znaczeń. Sobór w swoim wykładzie w największym stopniu odwołuje się do obrazu Ciała Chrystusa, chociaż wprost nie oparł się na nim w swojej eklezjologii. Szerzej odwołał się do obrazu Kościoła jako nowego ludu Bożego. Może to nieco zaskakiwać, biorąc pod uwagę, że sobór wypowiada się 20 lat po encyklice Mystici Corporis papieża Piusa XII, która szeroko wypłynęła na życie Kościoła i na kształt eklezjologii w okresie przedsoborowym. Celem dowartościowania doktryny mistycznego Ciała Chrystusa było uniknięcie w eklezjologii tendencji jurydycznych (które zresztą zawsze muszą być w niej obecne), ale w jeszcze większym stopniu miała na celu pozytywne pokazanie dogłębnej i żywotnej więzi zachodzącej między Chrystusem i Kościołem, jak również zwrócenie uwagi na powiązania społeczne jego członków, które wyrastają z eklezjalnej więzi z Chrystusem i w niej się spełniają. Oczywiście nie była to propozycja nowa, ponieważ już w okresie I Soboru Watykańskiego eklezjologia Ciała Chrystusa odrywała znaczącą rolę i wpłynęła na kształt jego wypowiedzi eklezjologicznych. Nowy w pewnym sensie był rozmach, z jakim przystąpiono do wprowadzania tych idei w życie.

W pierwszej połowie $\mathrm{xx}$ wieku została zaproponowana przez wielu teologów eklezjologia ludu Bożego ${ }^{11}$. Ma ona mocne zakorzenienie w Starym Testamencie i zwraca uwagę, w jaki sposób Kościół urzeczywistnia swoją wędrówkę historyczną jako lud pod znakiem przymierza zawartego przez Boga. Obraz ten nie zakłada bezpośredniego odniesienia do Chrystusa, ale zwraca uwage na wymiar antropologiczny, historyczny i socjologiczny Kościoła - jest to eklezjologia, która wyraźnie dowartościowuje jego widzialny wymiar. Konstytucja Lumen gentium, mając na uwadze potrzebę mocnego złączenia Kościoła z Chrystusem, stwierdza jednak: „Głową tego mesjańskiego ludu jest Chrystus” (LG 9). Pogłębienie tego zdania można widzieć w dalszym wyjaśnieniu zawartym w dokumencie, gdy zostaje powiedziane, że nowy lud Boży został „ustanowiony przez Chrystusa dla komunii życia, miłości i prawdy”, a „używany jest jako narzędzie zbawienia wszystkich” (LG 9). Zdanie to przypomina pierwszorzędne dary udzielone przez Chrystusa człowiekowi, a odniesienie do „narzędzia zbawienia” wyraźnie odsyła do sakramentalności Kościoła, która może mieć zakorzenienie tylko w samym Chrystusie jako prasakramencie zbawienia. Lud Boży na głębszym poziomie swego istnienia

${ }^{11}$ Por. Y. Congar, Kościół, jaki kocham, tłum. A. Ziernicki, Kraków 1997, s. 9-38. 
jest rzeczywistością sakramentalną, i w tej perspektywie ma rozwijać swoje historyczne pielgrzymowanie.

Pomijając wszystkie konotacje, jakie są związane z obrazem ludu Bożego, trzeba przede wszystkim zauważyć, że został on wykorzystany, aby uniknąć jednostronnego przedstawiania Kościoła w kluczu hierarchicznym, a tym samym zamierza wyraźniej podkreślić, że Kościół jest zgromadzeniem wszystkich chrześcijan, a więc ma charakter wspólnotowy i uniwersalny. Nie oznacza to jednak, że pojęcie ludu Bożego ma charakter ekskluzywny. Eklezjologia posoborowa pokazuje, że zależnie od okoliczności można, a nawet trzeba uwzględniać także inne obrazy, a nawet dawać im pierwszeństwo. Dlatego po soborze tak wielkiego znaczenia nabrało w eklezjologii pojęcie komunii ${ }^{12}$ albo „rodziny Bożej” ${ }^{\prime 3}$. Nie można zwłaszcza zapominać, że w nauczaniu soborowym ważne miejsce zajmuje obraz Ciała Chrystusa, a jego podstawowe znaczenie wynika $\mathrm{z}$ faktu, że zwraca uwagę na to, co najbardziej wewnętrzne w Kościele, czyli na jego pierwotną więź z Chrystusem, określającą jego postać oraz sposób urzeczywistniania się w dziejach. Jest to obraz konieczny, gdy chcemy uchrystologicznić rozumienie Kościoła jako nowego i pielgrzymującego ludu Bożego. Otwiera on także na wymiar pneumatologiczny Kościoła, który jest jego wymiarem integralnym i integrującym. Konstytucja Lumen gentium wyjaśnia: „[Chrystus] udzielając bowiem swego Ducha, ukształtował swoich barci wezwanych spośród wszystkich narodów jako swoje Mistyczne Ciało” (LG 7). W tym Ciele „duchowym” przekazuje On swoje życie, szczególnie przez sakramenty, chrzest i Eucharystię. Jest zasadą jedności, Głową uniwersalną, wzorem, do którego wszyscy mają się mozolnie dostosowywać. Prowadzi do wzrostu swoje Ciało, stale udzielając mu przede wszystkim daru posług. Doktryna Mistycznego Ciała pozwala zrozumieć działanie Jezusa Chrystusa jako zasady żywego wzrostu Kościoła w każdym czasie i we wszystkich sytuacjach duchowych.

Zarysowana wizja soborowa każe nam szukać nie tylko głębszych związków łączących Chrystusa i Kościól, ale także wskazać zasadnicze miejsce i egzystencjalne sposoby ich urzeczywistniania. W tym celu potrzebne będzie określenie głównych zasad, które opisują wewnętrzne związki Chrystusa z Kościołem.

${ }_{12}$ Por. G. Ghirlanda, „Hierarchica communio”. Significato della formula nella „Lumen gentium”, Roma 1980, passim.

${ }_{13}$ Por. F. Bechina, Die Kirche als „Familie Gottes”. Die Stellung dieses theologischen Konzeptes im Zweiten Vatikanischen Konzil in den Bischofssynoden von 1974 bis 1994 im Hinblick auf eine „Familia-Dei-Ekklesiologie”, Roma 1998, passim. 


\section{Zasada działalności kapłańskiej}

Jezus Chrystus Kapłan jest źródłem wszelkiej działalności, która została zlecona biskupom i prezbiterom; jako jedyny Pośrednik jest On pierwszym działającym. Konstytucja Lumen gentium podkreśla: „W osobach biskupów zatem, których pomocnikami są prezbiterzy, obecny jest wśród wiernych Pan Jezus Chrystus, Najwyższy Kapłan" (LG 21). Za ich pośrednictwem przepowiada słowo Boże, rozdziela sakramenty, wciela w swoje Ciało nowe członki, rządzi ludem Nowego Testamentu. Przez te stwierdzenia zostaje dowartościowana formuła: „działać w osobie Chrystusa”. Chrystus działa przez biskupa i prezbitera, a oni działają w Nim i przez Niego. Konsekracja biskupia udziela łaski Ducha Świętego i wyciska święty charakter, dzięki czemu - jak podkreśla konstytucja Lumen gentium - „biskupi w sposób szczególny i widoczny podejmują rolę samego Chrystusa Nauczyciela, Pasterza i Kapłana i działają w Jego osobie” (LG 21). Sakrament święceń udzielany także prezbiterom „naznacza [ich] szczególnym znamieniem i wskutek tego upodabniają się do Chrystusa Kapłana, tak że mogą działać w osobie Chrystusa Głowy" ${ }^{14}$. Wypowiedź $\mathrm{z}$ dekretu Presbyterorum ordinis uzupełnia formułę „działać w osobie Chrystusa”, stwierdzając, że chodzi o działanie „w osobie Chrystusa Głowy”. Z tej racji działanie kapłaństwa urzędowego zostaje odróżnione od kapłaństwa wspólnego, czyli „chrzcielnego”. Zakłada ono konsekrację, która uzdalnia do uczestniczenia za pośrednictwem składania duchowych ofiar, $w$ ofierze Chrystusa (LG 10). W działaniach biskupów i prezbiterów Chrystus dzieli się z nimi sobą samym jako Głowa i jako Pasterz. Z tej racji prezbiterzy są „sługami Głowy, jako współpracownicy stanu biskupiego, wznoszą i budują całe Jego Ciało, którym jest Kościół” (PO 12). Doktryna Ciała Chrystusa pozwala dobrze określić tę rolę prezbiterów, ponieważ włącza ich niejako od wewnątrz w tajemnicę Kościoła oraz wyznacza im w Kościele pierwszoplanową rolę i odpowiedzialność. Są oni „hierarchami” we właściwym znaczeniu, chociaż nie na tym samym stopniu święceń, co biskupi.

Pozycja Chrystusa w relacji do posługi kościelnej dobrze uwypukla Jego dwa przymioty. Jest On, jako Kapłan doskonały, najwyższym wzorem kapłaństwa, wzorem, który wpisuje się w posługi, ponieważ sakrament święceń upodabnia wyświęconego do Chrystusa Kapłana; On jest wzorem konsekracji kapłańskiej, służby, misji wychowawczej i formacyjnej, składania ofiary z siebie (PO 3, 6, 12). On jest zasadą życia kapłańskiego, aby jako wzór konkretnie

${ }^{14}$ Sobór Watykański II, Dekret o posłudze i życiu prezbiterów Presbyterorum ordinis [dalej: Po], nr 2, w: Sobór Watykański II, Konstytucje, dekrety, deklaracje, dz. cyt. 
manifestował się w życiu, posłudze i działaniach tych, których wybiera jako pasterzy. To jest Jego kapłaństwo jako Syna Wcielonego, który żyje w Kościele, w kapłaństwie powszechnym wszystkich ochrzczonych i ze szczególnych względów w kapłaństwie urzędowym.

Postawienie w centrum kapłaństwa kościelnego osoby Jezusa Chrystusa jest dalekie od zepchnięcia na margines rozwoju ludzkiej i indywidualnej osobowości kapłana czy też przysłonięcia jej; działanie Chrystusa pobudza ten rozwój, ukazuje jego perspektywy i doskonali go w sposób jak najbardziej skuteczny. Kapłaństwo powszechne zmierza do dowartościowania wszystkich zdolności ludzkich do składania ofiary i do podjęcia z poświęceniem życia chrześcijańskiego, sytuując je w perspektywie krzyża Chrystusowego. Kapłaństwo urzędowe prowadzi do owocnego realizowania działań „w osobie Chrystusa”. Chrystus Kapłan, działając za pośrednictwem wyświęconych do pełnienia posługi (ministri), wzbudza w nich uzdolnienia duchowe i eklezjalne, które pozwalają im wnosić także osobisty wkład w dzieło zbawienia. Chrystus nie likwiduje możliwego uczestniczenia człowieka w Jego kapłaństwie, ale włącza je ubogacone swoimi darami w swoje pośrednictwo oraz je odpowiednio ukierunkowuje, aby w sposób jak najbardziej właściwy służyło dziełu zbawczemu. Chrystus jest jedynym źródłem, prawdziwym źródłem, z którego wypływa Jego udzielające się zbawczo życie, a także wzorem Jego przyjmowania w konkretnej egzystencji i w pełnionej posłudze.

\section{Zasada życia liturgicznego}

Rola Chrystusa w liturgii jest tym ważniejsza, że liturgia nie jest rozumiana przez II Sobór Watykański jako jakieś proste wspomnienie minionych wydarzeń za pośrednictwem celebracji. Liturgia ma przede wszystkim charakter sprawczy i soteriologiczny. „W liturgii [...] «dokonuje się dzieło naszego Odkupienia»" "', a tym samym najbardziej autentycznie wyraża się więź wierzących z tajemnicą Chrystusa oraz natura prawdziwego Kościoła. Te stwierdzenia wystarczą do tego, by uznać prymat liturgii w życiu chrześcijańskim i jej niezastąpioną rolę w historycznym urzeczywistnianiu się zbawienia Chrystusowego. Trzeba przede wszystkim pamiętać, że dokonywanie się dzieła odkupienia jest możliwe dzięki działaniu samego Chrystusa oraz dzięki wykorzystaniu „środków”, które On dał do dyspozycji Kościołowi, a w nim każdemu wierzącemu. Aby zrozumieć to działanie, trzeba pamiętać, że liturgia

${ }^{15}$ Sobór Watykański II, Konsytucja o liturgii świętej Sacrosanctum Concilium [dalej: sc], nr 2, w: Sobór Watykański II, Konstytucje, dekrety, deklaracje, dz. cyt. 
ziemska jest uczestniczeniem w liturgii niebieskiej, „gdzie Chrystus zasiada po prawicy Boga jako sługa świątyni i prawdziwego przybytku” (sc 8). II Sobór Watykański w tej wypowiedzi inspiruje się perspektywą kapłaństwa niebieskiego obecną w Liście do Hebrajczyków; podkreśla ona, że Chrystus chwalebny spełnia posługę, która manifestuje się w liturgii Kościoła, prowadząc w nim do spełnienia się swego dzieła odkupieńczego. Zagadnienie to zasługuje na dalsze rozwinięcie w teologii, gdyż ukazuje ono wyjątkowy charakter kultu kościelnego ${ }^{16}$.

Można odnotować, że posługa Chrystusa, „zasiadającego po prawicy Ojca”, szczególnie dowartościowuje tajemnicę Jego wniebowstąpienia ${ }^{17}$. Liturgia często podkreślała znaczenie tej tajemnicy, czyniąc to wiele częściej niż teologia, która pozostawiła ją na marginesie swoich zainteresowań. Dzisiaj w ogóle uważa się, że tajemnica ta ma charakter czysto nominalistyczny, to znaczy nie wiąże się z żadnym wydarzeniem historycznym z życia Chrystusa, a tym samym nie ma znaczenia soteriologicznego i eklezjalnego. Sobór podkreślił, że Chrystus dokonał dzieła odkupienia i uwielbienia Boga „szczególnie przez paschalne misterium swojej błogosławionej męki, zmartwychwstania i chwalebnego wniebowstąpienia" (SC 5). Stwierdzenie soborowe zawiera niewątpliwie wezwanie do dowartościowania tajemnicy wniebowstąpienia Chrystusa w odniesieniu do liturgii, a zwłaszcza do jej skuteczności zbawczej oraz do jej znaczenia eschatologicznego. Sam Jezus podkreślił, że Eucharystia jest warunkiem życia wiecznego (por. J 6, 62). Trzeba ten fakt odkryć w odniesieniu do całej liturgii, a tym samym pokazać jej związek z wypełnieniem się życia ludzkiego w wieczności, ale zakorzenionego w doświadczeniu ziemskim. Liturgia zatem nie tylko służy uporządkowaniu naszych ziemskich doświadczeń, lecz nadaje im znaczenie w perspektywie eschatologicznej. Jawi się rzeczywiście jako „fons et culmen totius vitae christianae" (LG 11).

Innym ważnym elementem doktrynalnym w konstytucji o liturgii jest nauczanie o różnych sposobach obecności Chrystusa w liturgii. Ma ono swoje źródła już w encyklice Mediator Dei papieża Piusa XII (20 listopada 1947 r.), a po soborze zostało wyraźnie rozwinięte przez papieża Pawła vi w encyklice Mysterium fidei (3 września 1965 r.). Wypowiedź soborowa zaczyna się w sposób ogólny: „Chrystus jest obecny zawsze w swoim Kościele, zwłaszcza

${ }^{16}$ Por. W. Rzemiński, Eucharystia liturgia nieba i ziemi. Jedność celebracji eucharystycznej Kościoła z liturgia niebiańskiego Jeruzalem w ujęciu Cipriano Vagagginiego, Kraków 2011, passim.

${ }_{17}$ Por. J. Corbon, Liturgia źródło wody życia, tłum. A. Foltańska, Poznań 2005, s. 55-65. 
w czynnościach liturgicznych" (sc 7). Oznacza to, że liturgia jest wyjątkowym miejscem obecności Odkupiciela, której nic nie może przysłonićc ${ }^{18}$.

Aby wyrazić różne sposoby obecności Chrystusa, sobór posługuje się formułą: „Praesens adest”. Adest oznacza istnienie zwrócone do kogoś, wskazuje na rzeczywistość relacyjną. Nie chodzi więc tylko o działanie Chrystusa w liturgii, ale o Jego odniesienie do tych, którzy angażują się w działanie liturgiczne. Takie opisanie obecności wskazuje na relację międzyosobową, a sam Chrystus zostaje usytuowany w centrum relacji religijnych oraz wszystkich relacji międzyludzkich.

Chrystus „jest obecny w ofierze Mszy świętej tak w osobie celebrującego, gdyż «Ten sam, który kiedyś ofiarował siebie na krzyżu, obecnie ofiaruje się przez posługę kapłanów», jak zwłaszcza pod postaciami eucharystycznymi” (sc 7). Dwa sposoby obecności są ściśle powiązane ze sobą, ponieważ Chrystus jest obecny na ołtarzu na mocy faktu, że szafarz w Jego imieniu składa ofiarę i w Jego imieniu wypowiada słowa konsekracji. Są one jednak głęboko różne: $\mathrm{z}$ jednej strony chodzi o obecność, która dokonuje się subiektywnie przez posługę kapłana, a z drugiej strony jest to obecność Chrystusa „w miejscu” jako rzeczywistość obiektywna pod znakiem widzialnym. Ta obecność ma najbardziej wyjątkowy charakter - jest ona liturgicznym uobecnieniem obecności Słowa Wcielonego, na mocy której rodzi się nowa rzeczywistość duchowa, a jej uczestnicy znajdują się w nowej sytuacji egzystencjalnej.

Konstytucja o liturgii wyjaśnia obecność Chrystusa w sakramentach, odwołując się do stwierdzeń św. Augustyna: „Gdy ktoś chrzci, sam Chrystus chrzci” (sc 7). Chrystus jest obecny „swoją mocą”, ponieważ działa sakramentalnie, ale obecność nie może być sprowadzona do prostej czynności. Jeśli sobór dodał do encykliki Mediator Dei obecność w słowie, to oznacza to, że chciał uznać znaczenie tego słowa w liturgii, zwłaszcza gdy czyta się Pismo Święte i przepowiada. Obecność Chrystusa w tekstach świętych wyjaśnia się przez fakt, że On osobowo jest Słowem Bożym. W Nim utożsamia się osoba i słowo Boże, o którym świadczy Pismo Święte.

Konstytucja kontynuuje w tym samym punkcie: „Jest obecny, gdy Kościół modli się i śpiewa psalmy, gdyż On sam obiecał: «Gdzie są dwaj albo trzej zebrani w imię moje, tam jestem pośród nich» $(\mathrm{Mt} \mathrm{18,20)”.} \mathrm{Należy} \mathrm{pamiętać,}$ że Chrystus swoją modlitwą zapoczątkował modlitwę chrześcijańską i teraz nadal modli się w swoim Kościele. Modlitwa jest więc manifestacją obecności Chrystusa w Kościele i świecie oraz w coraz większym stopniu powinna być

18 Por. E. J. Kilmartin, Christian Liturgy, t. 1: Theology, Kansas City 1988, s. 303-355. 
wykorzystywana do tego, aby stawała się jej manifestacją. Oznacza to także, że z liturgii i modlitwy osobistej należy eliminować to wszystko, co mogłoby Jego obecność zaciemniać, a tym samym stawać się tylko ludzkim czynnikiem.

Konstytucja stwierdza więc dalej: „Słusznie zatem uważa się liturgię za wypełnianie kapłańskiej funkcji Jezusa Chrystusa”. To pierwszorzędne działanie Chrystusa nie wprowadza jakiegoś „chrystomonizmu”. Z jednej strony sobór podkreśla, że celem ostatecznym kultu jest Ojciec; Kościół, wzywając Chrystusa jako swego Pana, „za Jego pośrednictwem oddaje cześć Ojcu”. Z drugiej strony działanie Kościoła w liturgii jest zawsze złączone $\mathrm{z}$ działaniem Chrystusa: „Mistyczne Ciało Jezusa Chrystusa, to jest Glowa ze swymi członkami, sprawuje pełny kult publiczny”; każda celebracja liturgiczna jest „działaniem Chrystusa-Kapłana i Jego Ciała, czyli Kościoła”. Działanie Chrystusa nadaje najwyższą wartość działaniu Kościoła, a zatem dzięki temu: „skuteczności z tego samego tytułu i w tym samym stopniu nie posiada żadna inna czynność Kościoła”. Stwierdzenia te oznaczają, że liturgia jest i musi pozostać centralnym elementem w życiu Kościoła, a troska o nią jest wyrazem praktycznym chrystocentryzmu kościelnego oraz wzorem dla chrystocentryzmu chrześcijańskiego i dla jego doświadczeń duchowych.

Liturgiczna zasada odniesienia Kościoła do Chrystusa na pewno podkreśla, że jest On dogłębnie złączony z Kościołem w tym szczególnym momencie, jakim jest celebracja. Nie można jednak zapomnieć, że bliskość liturgiczna Chrystusa skłania do pytania się o to, w jaki sposób Jego obecność i Jego działanie liturgiczne powinny kształtować postawy chrześcijańskie, zarówno wspólnotowe, jak i indywidualne. Pojawia się tutaj kluczowe pytanie, na które nie ma łatwej odpowiedzi, a mianowicie: w jaki sposób ta obecność i działanie liturgiczne Chrystusa ma wzorczy charakter dla samego Kościoła także w odniesieniu do innych aspektów jego misji i jego aktywności w poszczególnych wspólnotach lokalnych. Na pewno musi tutaj powrócić zagadnienie „sakramentalnego stylu” życia chrześcijańskiego, o którym w swoim nauczaniu często mówił św. Jan Paweł II. W pewnym sensie jest ono synonimem wzorczości w stosunku do Kościoła, ponieważ za jego pośrednictwem można najwyraźniej kształtować zarówno osobistą, jak i wspólnotową więź z Chrystusem.

\section{Zasada działalności apostolskiej i misyjnej}

Jezus Chrystus jako zasada życia Kościoła jest źródłem całej działalności apostolskiej i misyjnej. II Sobór Watykański w konstytucji Lumen gentium podkreślił w odniesieniu do apostolatu świeckich: „Najwyższy i Przedwieczny Kapłan, Jezus Chrystus, pragnąc, aby Jego świadectwo i Jego posługa trwały 
nieprzerwanie także za pośrednictwem ludzi świeckich, ożywia ich swoim duchem i nieustannie zachęca do każdego szlachetnego i doskonałego dzieła” (LG 34). On sam przekazuje wszystkim wiernym część swego urzędu kapłańskiego w celu pełnienia kultu duchowego; przez ich świadectwo pełni On swoją funkcję prorocką; przez nich rozszerza swoje królestwo, przez nich wyraża swoje uniwersalne panowanie i swoją boską i zbawczą władzę (LG 34-35). Wynika z tego norma, która kieruje apostolatem: „Skoro Chrystus przysłany przez Ojca jest źródłem i początkiem całego apostolstwa Kościoła, jest rzeczą oczywistą, że owocność apostolstwa świeckich zależy od ich żywotnego zjednoczenia z Chrystusem"19. Jest to odzwierciedlenie słów samego Chrystusa: „Kto trwa we Mnie, a Ja w nim, ten przynosi owoc obfity, ponieważ beze Mnie nic nie możecie uczynić" (J 15, 5 $)^{20}$.

Aby wyrazić podstawę doktrynalną działalności misyjnej, soborowy dekret Ad gentes ukazuje jej sens w zbawczym posłaniu Syna i posłaniu Ducha Świętego zgodnie z zamysłem Ojca. Podkreśla, że „Chrystus Jezus został [...] posłany na świat jako prawdziwy pośrednik między Bogiem a ludźmi”21. Jako Bóg i Człowiek - na mocy prawdziwego i historycznego wcielenia - przyszedł, aby uczynić ludzi uczestnikami natury Bożej. Przyszedł, aby dać swoje życie na okup za wielu, wyrwać ludzi spod panowania Szatana, dokonać pojednania świata $\mathrm{z}$ Bogiem, ocalić to, co zginęło, a tym samym został ustanowiony Głową odrodzonej ludzkości. „To zaś, co raz zostało przepowiedziane przez Pana albo w Nim dokonane dla zbawienia rodzaju ludzkiego, powinno być głoszone i rozpowszechniane aż po krańce ziemi” (AG 3). Dla wypełnienia tego zamysłu Chrystus posłał od Ojca Ducha Świętego, który w ciągu wieków kontynuuje Jego dzieło.

Zadanie głoszenia wiary i zbawienia Chrystusowego powierzone Kościołowi wynika z ewidentnego nakazu danego przez Chrystusa apostołom i ich następcom, a urzeczywistnia się na mocy żywego wpływu przekazywanego przez Chrystusa swoim członkom. „Misja ta trwa bezustannie i na przestrzeni dziejów rozszerza posłannictwo samego Chrystusa, który został posłany, aby głosić ubogim Dobrą Nowinę" (AG 5). Działalność misyjna realizuje się więc na mocy woli samego Chrystusa, a konkretyzuje się w Duchu Świętym,

19 Sobór Watykański II, Dekret o apostolstwie świeckich Apostolicam actuositatem, nr 4, w: Sobór Watykański II, Konstytucje, dekrety, deklaracje, dz. cyt.

${ }^{20}$ K. Wojtyła, Kościół w tajemnicy odkupienia..., dz. cyt., s. 136-148.

${ }^{21}$ Sobór Watykański II, Dekret o misyjnej działalności Kościoła Ad gentes [dalej: AG], nr 3, w: Sobór Watykański II, Konstytucje, dekrety, deklaracje, dz. cyt. 
który rozdziela łaskawie Jego boskie życie i Jego dary. Stanowią one i powinny stanowić „duszę” wszelkiej aktywności wiernych, począwszy od aktywności wewnętrznej, aż do najszerszej aktywności misyjnej ${ }^{22}$.

Chrystus jako zasada działalności apostolskiej i misyjnej wyznacza zasadnie szukania Jego wzorczego znaczenia w aspekcie dynamicznym, to znaczy przede wszystkim w odniesieniu do podejmowanych działań. Nie można odrywać stylu zaangażowania kościelnego od konkretnych działań spełnionych przez Chrystusa, od ich specyfiki oraz od wyznaczonych im celów. Niejednokrotnie zachodzi sytuacja, w której działania kościelne zbytnio upodabniają się do działań podejmowanych w środowiskach świeckich, zwłaszcza w nurcie życia politycznego. Kościół w swoich działaniach musi zachować swoją odrębność, która jest tak bardzo wyraźnie obecna w działaniach Chrystusa, niewahającego się różnić od działań swoich współczesnych. Zachowuje kluczowe znaczenie wezwanie Chrystusa skierowane do uczniów: „Wy zaś nie tak macie postępować” (Łk 22, 26).

Stwierdzenia dotyczące chrystologii zasady apostolskiej i misyjnej w odniesieniu do Kościoła domagają się szczególnego przemyślenia w aspekcie eklezjalnym. Nie kwestionując tradycyjnego modelu „naśladowania Chrystusa”, zawartego we wpływowej średniowiecznej książeczce o takim samym tytule, trzeba dzisiaj podkreślić - czego w niej właśnie brakuje - że to naśladowanie powinno w większym stopniu wyrazić się w wymiarze eklezjalnym życia chrześcijańskiego ${ }^{23}$. Taki postulat stawia zadanie głębszego przemyślenia, na czym powinno polegać „doświadczenie eklezjalne” w odniesieniu do różnych form życia w Kościele oraz w jaki sposób powinno ono stanowić punkt odniesienia dla osobistych wyborów i osobistego zaangażowania kościelnego ${ }^{24}$.

\section{Chrystus i tajemnica człowieka}

Mając na uwadze relację Chrystusa do Kościoła, a zarazem pytając się o Jego wzorcze znaczenie dla Kościoła, trzeba sięgnąć także do Konstytucji duszpasterskiej o Kościele w świecie współczesnym Gaudium et spes. Dzisiaj, po

${ }_{22}$ Por. A. M. Triacca, Lo Spirito Santo nella liturgia e nella vita della Chiesa, Città del Vaticano 2011, s. 299-318.

${ }^{23}$ Por. J. Królikowski, Miłość i naśladowanie Chrystusa, w: Umiłować Chrystusa. Program duszpasterski na rok 2002/2003, Katowice 2002, s. 59-69.

${ }^{24}$ Por. H. U. von Balthasar, Kirchenerfahrung dieser Zeit, w: Sentire Ecclesiam. Festschrift für Hugo Rahner, Hrsg. J. Daniélou, H. Vorgrimler, Freiburg-Basel 1961, s. 743-768. 
początkowym entuzjazmie i uznaniu jej nawet za najwyższy wyraz profetyzmu II Soboru Watykańskiego, konstytucja należy do dokumentów soborowych, którymi mało interesuje się eklezjologia i w ogóle teologia, podczas gdy posiada on ciągle ważne znaczenie dla określenia relacji Kościoła w stosunku do świata - relacji, która jest kształtowana w kluczu chrystologicznym. Można to zauważyć, gdy uwzględni się zwłaszcza dwie kwestie, a mianowicie indywidualną i społeczną antropologię konstytucji Gaudium et spes, która wyznacza Kościołowi, a w nim wszystkim wierzącym kryteria odnoszenia się do człowieka jako osoby i do wspólnoty osób, a więc do człowieka jako istoty społecznej.

\section{Pojedynczy człowiek}

W stosunku do człowieka Jezus Chrystus spełnia wyjątkową funkcję objawiającą: „W istocie misterium człowieka wyjaśnia się prawdziwie jedynie w misterium Słowa Wcielonego. [...] Chrystus, nowy Adam właśnie w objawieniu tajemnicy Ojca i Jego miłości objawia w pełni człowieka samemu człowiekowi i odsłania przed nim jego najwyższe powołanie"25. Objawienie, w którym Bóg ukazuje człowiekowi swoją tajemnicę, jest równocześnie objawieniem człowieka. Chrystus, objawiając Ojca i człowieka, dokonuje równocześnie dzieła jego naprawy: Chrystus ,jest zarazem doskonałym człowiekiem, który przywrócił synom Adama podobieństwo Boże, zniekształcone przez grzech pierworodny" (GS 22). Aby uwypuklić ten aspekt dzieła Chrystusa, sobór w swoim nauczaniu zwraca najpierw uwagę na wcielenie, a dopiero potem przechodzi do włączenia w swój wykład kwestii odkupieńczej ofiary Chrystusa.

Syn Boży we wcieleniu, stając się doskonałym człowiekiem, wyniósł naturę ludzką do szczególnej godności. Z jednej strony stał się podobny do nas, z wyjątkiem grzechu, ale także - z drugiej strony - „przez wcielenie zjednoczył się w pewien sposób z każdym człowiekiem" (GS 22). Wypowiedź ta wskazuje, że Syn Boży - mimo iż przyjął indywidualną naturę ludzką - dokonał przekształcenia kondycji wszystkich ludzi. Wcielenie ma odniesienia uniwersalne, gdyż opiera się na nieskończonej wartości boskiej osoby Syna, i z tej racji powinno się szukać jego uniwersalnych odniesień do rzeczywistości ludzkiej. Nic nie może pozostawać poza sferą zainteresowania Kościoła.

Sobór dopełnia to nauczanie odniesieniem do odkupienia, w którym niewinny Baranek wysłużył nam życie przez wylanie swojej krwi: „W Nim Bóg pojednał nas ze sobą, a także między nami, i wyrwał nas z niewoli diabła

${ }^{25}$ Sobór Watykański II, Konstytucja duszpasterska o Kościele w świecie współczesnym Gaudium et spes [dalej: Gs], nr 22, w: Sobór Watykański II, Konstytucje, dekrety, deklaracje, dz. cyt. 
i grzechu" (GS 22). Tajemnica paschalna, tak jak tajemnica wcielenia, zwraca się do całej ludzkości i do wszystkich dziedzin jej życia. Chrześcijanie są dogłębnie złączeni z tą tajemnicą, zwłaszcza wtedy gdy walczą ze złem, nawet za cenę wielu wyrzeczeń i podejmowanego poświęcenia. To samo trzeba powiedzieć o ludziach dobrej woli, ponieważ „ostatecznie powołanie człowieka jest w istocie jedno, mianowicie Boskie”, a „Duch Święty wszystkim daje możliwość uczestniczenia w tym misterium paschalnym w tylko Bogu znany sposób” (Gs 22).Z tej racji także „przez Chrystusa i w Chrystusie więc rozświetlana jest tajemnica cierpienia i śmierci” (Gs 22). Problem cierpienia i śmierci, który nieustannie niepokoi serce i umysł człowieka, a dzisiaj jest ideologicznie spychany na margines ludzkich pytań, domaga się zatem odniesienia do Chrystusa Odkupiciela i jedynie w Nim znajduje spójną odpowiedź. Należy zdecydowanie bronić krzyża nie tylko w „sferze publicznej”, ale trzeba pamiętać, że podstawą i ośrodkiem tej obrony jest bronienie jego centralnego miejsca w doświadczeniu chrześcijańskim. Krzyż musi pozostać „słowem”, które się wypowiada nieustannie i w każdej okoliczności, także wobec jego przeciwników, którzy uznają go za głupstwo, jak mówi św. Paweł (1 Kor 1, 18). Mówić zaś o krzyżu Chrystusa oznacza mówić o jego znaczeniu dla człowieka, o zawartej w nim wiecznej mądrości, oraz pokazywać sposoby łączności ludzkiego krzyża z krzyżem Zbawiciela. Trzeba mocno zwracać uwagę, aby krzyża Chrystusa nie zastąpić jednostronnie krzyżem człowieka, jakimś „,krzyżem humanistycznym”, który bez odniesienia do krzyża, na którym umarł Syn Boży, jest pozbawiony sensu. Mówienie o krzyżu humanistycznym ma pewną wymowę, ale jest ona za słaba, by można było w nim widzieć źródło zbawienia, czy też w oparciu o niego przemieniać i kształtować ludzkie życie. Osobiste odniesienie do Syna Bożego na krzyżu pozostaje normą życia chrześcijańskiego i nie zastąpi go żadne odniesienie, np. do uchodźców, jak mogliśmy to słyszeć nawet w bardzo szczególnej religijnie sytuacji, jaką była droga krzyżowa w czasie Światowych Dni Młodzieży w Krakowie w 2016 roku, czy do jakiegokolwiek „krzyża” tylko ludzkiego.

Wyjątkowego, niejako dopełniającego znaczenia w uchwyceniu wielkości tajemnicy człowieka nabiera tajemnica zmartwychwstania: „Chrystus zmartwychwstał, unicestwiając śmierć swoją śmiercią, i szczodrze udzielił nam swojego życia, abyśmy, synowie w Synu, wołali w Duchu: Abba, Ojcze!” (Gs 22). Zmartwychwstały Pan jest więc źródłem boskiego życia i synostwa Bożego. Wszyscy ludzie są podmiotami Jego przekształcającego oddziaływania: „Przez moc swojego Ducha działa już w sercach ludzkich” (Gs 38). Oczyszcza On i umacnia szlachetne pragnienia, które zmierzają do ulepszenia społeczności ludzkiej, oraz sprawia, że ukazuje się w nich „nowe stworzenie”, o którym 
mówi Nowy Testament. Oznacza to, że życie chrześcijańskie domaga się autentycznej duchowości paschalnej, a Wielkanoc i każde jej niedzielne przedłużenie ma stawać się podstawą doświadczenia chrześcijańskiego i kluczowym momentem, który je oczyszcza, kształtuje i formuje. Chrześcijanin ma być „człowiekiem dnia Pańskiego”, jak określali swoją tożsamość starożytni chrześcijanie. „Nie możemy żyć bez niedzieli” - tak mówili oni, i także my mamy tak mówić. Obrona niedzieli jest niebagatelnym aspektem tej duchowości wobec dzisiejszych wyzwań. Oznacza to również konieczność pokazania, w jaki sposób można by i należałoby ją przeżywać w pełni po chrześcijańsku, czyli w najwyższym stopniu eklezjalnie.

\section{Społeczność ludzka}

Zwracając uwagę na zasadniczą sprawę, którą jest przemiana indywidualnego przeznaczenia człowieka, II Sobór Watykański podkreśla także wkład Chrystusa w odniesieniu do jego przeznaczenia wspólnotowego. Słowo Wcielone zechciało wejść do wspólnoty ludzkiej, wyrażając solidarność z ludźmi we wszystkich aspektach ich życia: „Był obecny podczas godów w Kanie, wstąpił do domu Zacheusza, jadał razem z celnikami i grzesznikami” (Gs 32). W odniesieniu do życia codziennego ludzi Jezus dokonywał objawienia Ojca oraz piękna ich powołania. Dokonał odkupienia i uświęcenia relacji międzyludzkich, szczególnie relacji rodzinnych. Poddał się prawom i zwyczajom swojej ojczyzny oraz prowadził życie na takim samym poziomie, jak i współcześni $\mathrm{Mu}$ rodacy. W pełnym tego słowa znaczeniu Chrystus należy do ludzkości, stanowiąc jej centrum osobowe i duchowe.

Jezus chciał przede wszystkim zainaugurować nową jedność pośród ludzi. Swoim przepowiadaniem potwierdził obowiązek dzieci Bożych, by odnosić się do siebie jako bracia; modlił się o jedność; ofiarował się za wszystkich. Zobowiązał swoich apostołów do głoszenia orędzia ewangelicznego, , ,aby rodzaj ludzki stał się rodziną Bożą, w której pełnię prawa stanowiłaby miłość” (GS 32). Jezus określił więc nowy typ relacji, którymi powinien promieniować rodzaj ludzki, właśnie relacji rodzinnych. Ta nowa rodzina ludzka została już zapoczątkowana: „Pierworodny pośród wielu braci, pośród wszystkich, którzy przyjmują Go z wiarą i miłością, po swojej śmierci i zmartwychwstaniu ustanowił przez dar swojego Ducha nową braterską wspólnotę w swoim Ciele, Kościele, w którym wszyscy są dla siebie wzajemnie członkami i winni świadczyć sobie nawzajem posługi zgodnie z różnymi darami, jakie zostały im udzielone" (GS 32). Autentyczność kościelna powinna wyrażać się we wzajemnej pomocy i we wzroście solidarności w powszednich okolicznościach życia. 
Powinna charakteryzować się nową relacyjnością, czerpiącą wzór z nauczania i postawy samego Jezusa.

Konstytucja Gaudium et spes podkreśla, że rola „założycielska” Chrystusa w odniesieniu do Kościoła ma ważny wpływ na całą społeczność ludzką: „Jedność rodziny ludzkiej wyraźnie dopełnia się i umacnia opartą na Chrystusie jednością rodziny dzieci Bożych" (Gs 42). Odniesienie Chrystusa do całego rodzaju ludzkiego jest tym ważniejsze, że podkreśla nadprzyrodzone znaczenie społeczności oraz różnych aspektów jej życia i rozwoju. Porządek odkupienia obejmuje porządek stworzenia, do którego należy społeczność ludzka, dlatego też tajemnica Kościoła w sposób konieczny rozciąga się na całość rzeczywistości i ludzkich problemów. Konstytucja Gaudium et spes nie waha się zwrócić uwagę, że wpływ Chrystusa obejmuje także cały kosmos: „Będąc doskonałym człowiekiem, wszystkich zbawia i wszystko rekapituluje w sobie” (Gs 42). Całe dzieje zmierzają do Chrystusa: „Pan jest celem historii ludzkiej, punktem, ku któremu zwracają się pragnienia historii i cywilizacji, ośrodkiem rodzaju ludzkiego, radością wszystkich serc i wypełnieniem ich tęsknot” (Gs 45).

Przed chrześcijanami, wobec dzisiejszych nacisków ideologicznych, stoi zadanie bronienia relacyjnego rozumienia i przeżywania przynależności społecznej. Dzisiejsze kształtowanie życia społecznego jako opartego na pełnionych funkcjach, których zakres zostaje określony tylko formalnie, przede wszystkim za pośrednictwem procedur i ustaw, kwestionuje nauczanie Chrystusa, który domaga się od swoich uczniów „większej” sprawiedliwości, czyli bardziej twórczego i odpowiedzialnego udziału w życiu społeczności ludzkiej. Zakłada to właśnie bardziej relacyjne rozumienie człowieka oraz jego zaangażowania społecznego, gdyż tylko w ten sposób człowiek będzie mógł wyrażać i rozwijać swoją wolność, a tym samym naczelne prawo miłości, które jest źródłem zbawienia. Obecność chrześcijan w świecie nie może być sprowadzona do jakiegoś formalizmu, który ograniczy się do bezwiednego i jednostronnego odpowiadania na wymogi określane przez innych, nawet jeśli byłoby to podyktowane wzniosłymi celami. Tradycja chrześcijańska broni także podmiotowości człowieka w wymiarze społecznym, widząc w nim odpowiedź na dzieło zbawcze Chrystusa i wyraz udziału w życiu Kościoła.

\section{Zakończenie: Chrystus obecny w całym Kościele}

Eklezjologia II Soboru Watykańskiego niewątpliwie ma głębokie zakorzenienie w chrystologii i soteriologii. Nie chodzi tutaj tylko o jakąś „chrystologię pośrednią”. Nawet jeśli chrystologiczny punkt wyjścia nie zawsze jest 
ewidentny w nauczaniu soborowym, to jednak w kluczowych momentach wykładu soborowego odniesienie do chrystologii pozostaje fundamentalne, nabierając także znaczenia normatywnego. Tajemnica odkupieńczego wcielenia pozostaje niekwestionowaną inspiracją dla nauczania soborowego zarówno $\mathrm{w}$ jego całości, jak w jego rozmaitych elementach i aspektach. Na mocy tej tajemnicy Jezus Chrystus ukonstytuował historycznie Kościół i nadal wywiera na niego swoje determinujący wpływ, określające jego aktualny kształt i jego aktywność. Gdy przyszedł na ziemię Syn Wcielony, ukonstytuował swój Kościół, zaopatrując go w strukturę hierarchiczną opartą na sakramencie święceń, wokół którego rozwija się całe eklezjalne życie. Po wstąpieniu do chwały po swoim zmartwychwstaniu Chrystus pozostaje zasadą światła i życia dla nowego i pielgrzymującego ludu Bożego, który jest Jego Ciałem i sakramentem zbawienia. We wszystkich aspektach działania kościelnego to On jest pierwszym, który działa. Aby jednak to działanie mogło być skuteczne i widoczne, Kościół musi upodabniać się do Chrystusa, gdyż tylko w ten sposób to, co niewidzialne, będzie mogło ujawnić swój własny blask i swoją pełną skuteczność. Można syntetyzująco powiedzieć, że Kościół na tyle będzie widzialny i wymowny w swej widzialności, na ile będzie dawał pierwszeństwo - zarówno indywidualnie, jak i wspólnotowo - niewidzialnej więzi łączącej go z Jezusem Chrystusem oraz na ile będzie ją wyrażał i utrwalał w swojej aktywności w świecie.

W takim ujęciu nie ma jakiegoś „chrystomonizmu”, ponieważ nauczanie II Soboru Watykańskiego stara się usytuować Jezusa Chrystusa w ramach zamysłu Ojca, którego wewnętrznym wyrazem i przejawem ciągłości jest Kościół. Syn jest posłany przez Ojca i działa za pośrednictwem Ducha Świętego, ale to posłanie i działanie urzeczywistnia się eklezjalnie. Jego działanie dominujące w życiu Kościoła nie pomniejsza działań członków Jego Ciała, ale stanowi dla nich wzór, a jeśli jest On przyjęty, obdarza podejmowane działania swoją boską mocą, które w ten sposób nabierają pełnego znaczenia i pierwszeństwa w budowaniu Kościoła jako budowli z żywych kamieni. Jak wielokrotnie podkreślił papież Benedykt xvi w swoim nauczaniu, należy na pierwszym miejscu zawsze pamiętać, że Kościół jest Jego, to znaczy Jezusa Chrystusa, a nie nasz. Na tej zasadzie powinniśmy opierać nasze uczestnictwo w Kościele.

Chrystus prowadzi swój Kościół do uczestniczenia w tajemnicy paschalnej, a przez Kościół prowadzi do udziału w niej całą ludzkość. Objawia człowieka samemu człowiekowi, przekształca warunki jego życia, zapoczątkowuje relacyjną wspólnotę braterską, otwiera na wypełnienie eschatologiczne. Chrystus 
rządzi biegiem dziejów, panuje nad Kościołem i nad światem ${ }^{26}$, dlatego też celem ostatecznym dziejów jest rekapitulacja w Nim wszystkich rzeczy. Z obecności i działania Jezusa Chrystusa w Kościele wyłania się stopniowo Jego „Pełnia” ( pleroma), jak mówi św. Paweł $(\mathrm{Kol} 1,19)$. Każdy wierzący może czuć się w Kościele uczestnikiem największego dzieła, które dokonuje się w świecie, a którym jest dzieło zbawienia.

\section{ABSTRAKT}

Eklezjologia II Soboru Watykańskiego stanowi niezmiennie punkt odniesienia dla każdej autentycznej refleksji o Kościele, o jego misji oraz o sposobach jego kształtowania w perspektywie rozwoju historycznego. Nauczanie ostatnich papieży zwraca uwagę na potrzebę odniesienia Kościoła do Chrystusa jako jego wzoru. Aby to zalecenie móc wypełnić, konieczne jest sięgnięcie do nauczania II Soboru Watykańskiego, pytając się, w jaki sposób i w jakich aspektach jego nauczanie ukierunkowuje Kościół na jego wzór, który osobowo określa sam Jezus Chrystus. Niniejszy artykuł stara się udzielić odpowiedzi na to pytanie, zwracając najpierw uwagę na początek Kościoła w Jezusie Chrystusie, aby na tym tle określić, w jaki sposób i w jakim zakresie treściowym jest On zasadą życia Kościoła i jego wzorem. Dopełnieniem refleksji ściśle eklezjologicznej jest zwrócenie uwagi na aspekty antropologii indywidualnej i społecznej, którą znajdujemy w nauczaniu soborowym. W tej ostatniej kwestii chodzi o wskazanie na wzorczość antropologiczną Chrystusa, którą powinien uwzględniać Kościół w pełnieniu swojej misji zbawczej.

\section{SŁOWA KLUCzowe}

eklezjologia, chrystologia, antropologia, hierarchia, liturgia, zbawienie, wzór

\section{Abstract}

\section{Christ as the example for the Church in perspective of the Second Vatican Council}

The ecclesiology of the Second Vatican Council constitutes invariably a benchmark for every authentic reflection regarding the Church, its mission and the ways of its shaping in perspective of historic development. The teachings of the recent popes draw our attention to the need of referring the Church to Christ as its paradigm. To make this requirement possible to fulfil it is necessary to derive from the teachings of the Second

${ }^{26}$ Por. Y. Congar, La signeurie du Christ sur l'Église et sur le mond, „Istina” 6 (1959) s. 131-166. 
Vatican Council, inquiring how and in what aspects its teaching directs the Church towards the pattern which Jesus Christ defines himself personally. This article tries to provide an answer to this question pointing out, in the first place, the beginning of the Church in Jesus Christ. Thus, in this context it tries to determine in what way and to what extent $\mathrm{He}$ is the principle of life of the Church and the example for it. The emphasis on the aspect of individual and social anthropology which can be found in the teachings of the Council is the fulfilment of the strictly ecclesiological reflection. This last issue concentrates on the stressing of the idea of Christ being the anthropological example, which should be included by the Church in the fulfilment of its salutary mission.

\section{KEYWORDS}

ecclesiology, Christology, anthropology, hierarchy, liturgy, salvation, example

\section{BIBLIOGRAFIA}

Balthasar H. U. von, Kirchenerfahrung dieser Zeit, w: Sentire Ecclesiam. Festschrift für Hugo Rahner, Hrsg. J. Daniélou, H. Vorgrimler, Freiburg-Basel 1961, s. 743-768.

Bechina F., Die Kirche als „Familie Gottes”. Die Stellung dieses theologischen Konzeptes im Zweiten Vatikanischen Konzil in den Bischofssynoden von 1974 bis 1994 im Hinblick auf eine „Familia-Dei-Ekklesiologie”, Roma 1998.

Congar Y., La signeurie du Christ sur l'Église et sur le mond, „Istina” 6 (1959) s. 131-166. Congar Y., Kościót, jaki kocham, tłum. A. Ziernicki, Kraków 1997.

Corbon J., Liturgia źródło wody życia, tłum. A. Foltańska, Poznań 2005.

Franciszek, Adhortacja apostolska Evangelii gaudium (24 listopada 2013), Kraków 2013. Gherardini B., Lenciclica „Mystici Corporis” (29 giugno 1943), w: L’eredità del magistero di Pio XII, ed. Ph. Chenaux, Città del Vaticano 2010, s. 203-217.

Ghirlanda G., „Hierarchica communio”. Significato della formula nella „Lumen gentium", Roma 1980.

Jan Paweł II, Katecheza w czasie audiencji generalnej (6 sierpnia 1997 r.), 4, „L'Osservatore Romano" (wyd. pol.) 18 (1997) nr 11, s. 21.

Kilmartin E. J., Christian Liturgy, t. 1: Theology, Kansas City 1988.

Królikowski J., Miłość i naśladowanie Chrystusa, w: Umiłować Chrystusa. Program duszpasterski na rok 2002/2003, Katowice 2002, s. 59-69.

Królikowski J., Jezus Chrystus prasakrament Boga i zbawienia, „Tarnowskie Studia Teologiczne" 26 (2007) nr 2, s. 3-18.

Philipon M., La Santissima Trinità e la Chiesa, w: La Chiesa del Vaticano II. Studi e commenti intorno alla costituzione dommatica "Lumen gentium”, opera collettiva diretta da G. Baraúna, Firenze 1965, s. 329-350. 
Ratzinger J., Kościół - znak wśród narodów. Pisma eklezjologiczne i ekumeniczne, tłum. W. Szymona, Lublin 2013 (Opera omnia, viII/1).

Rzemiński W., Eucharystia liturgia nieba i ziemi. Jedność celebracji eucharystycznej Kościoła z liturgia niebiańskiego Jeruzalem w ujęciu Cipriano Vagagginiego, Kraków 2011.

Triacca A. M., Lo Spirito Santo nella liturgia e nella vita della Chiesa, Città del Vaticano 2011.

Sobór Watykański II, Konstytucje, dekrety, deklaracje, Poznań 2002.

Wojtyła K., Kościół w tajemnicy odkupienia. Interpretacja Vaticanum II, wybór i oprac.

A. Dobrzyński, Rzym 2012. 